\title{
Strategi Adaptasi Pedagang Pasa Ateh Bukittinggi Pasca Kebakaran di Pasar Penampungan
}

\author{
Yulia Sandra', Ikhwan Ikhwan', Nora Susilawati ${ }^{3}$ \\ 1,2,3 Universitas Negeri Padang \\ email: yuliasandra333@gmail.com
}

\begin{abstract}
Abstrak
Penelitian ini bertujuan untuk menjelaskan dan mendeskripsikan strategi adaptasi pedagang Pasa Ateh Bukittinggi pasca kebakaran di pasar penampungan. Penelitian ini dianalisis dengan menggunakan teori struktural fungsional yang dikemukakan oleh Talcott Parsons. Penelitian ini menggunakan pendekatan kualitatif dengan tipe penelitian studi kasus. Pemilihan informan dilakukan secara purposive sampling dengan jumlah informan 25 orang. Pengumpulan data dilakukan dengan cara observasi partisipasi pasif, wawancara mendalam, dokumentasi, serta validitas data dilakukan dengan triangulasi data. Data yang diperoleh dianalisis dengan menggunakan analisis interaktif seperti yang dikembangkan oleh Miles dan Huberman dengan langkah-langkah pengumpulan data, reduksi, penyajian dan kesimpulan. Hasil penelitian dari strategi adaptasi pedagang Pasa Ateh Bukittinggi pasca kebakaran di pasar penampungan adalah; 1) berdagang di kios yang dibangun pemerintah, 2) membangun keakraban antar pedagang, 3) mempercantik ruang dan penataan barang yang menarik, 4) mempromosikan barang dagangan kepada konsumen.
\end{abstract}

Kata Kunci: Pedagang, Strategi Adaptasi, Pasca Kebakaran

\section{Abstract}

This study aims to explain and describe the Pasa Ateh Bukittinggi merchant adaptation strategy after the fire in the shelter market. This study was analyzed using functional structural theory proposed by Talcott Parsons. This study uses a qualitative approach with a type of case study research. The selection of informants was done by purposive sampling with 25 informants. Data collection was carried out by means of passive participation observation, in-depth interviews, documentation, and data validity carried out by data triangulation. The data obtained were analyzed using interactive analysis as developed by Miles and Huberman with the steps of data collection, reduction, presentation and conclusion. The results of the research of the Pasa Ateh Bukittinggi merchant adaptation strategy after the fire in the shelter market are; 1) trading in kiosks built by the government, 2) build familiarity between traders, 3) beautify the space and arrangement of interesting items, 4) promoting merchandise to consumers

Keywords: Trader, Adaptation strategy, Post fire. 


\section{Pendahuluan}

Pasa Ateh merupakan salah satu pasar yang menjadi daya tarik di Kota Bukittinggi, barang yang ditawarkan beragam mulai dari pakaian, makanan hingga barang khas Sumatera Barat seperti kerajinan songket dan souvenir. Pedagang di pasar ini dikelompokkan berdasarkan jenisnya sehingga memudahkan pembeli mencari barang yang diinginkannya. Daya beli masyarakat relatif tinggi karena pasar ini terletak bersebelahan dengan taman Jam Gadang, sehingga secara tidak langsung para pengunjung Jam Gadang bisa berbelanja di Pasa Ateh untuk membeli oleh-oleh.

Pasa Ateh mengalami hambatan karena terjadi kebakaran yang menghanguskan banyak toko, membuat pedagang harus menata kembali usahanya yang hancur di Pasar Penampungan. Di Pasar Penampungan kios berukuran 2x1,75 meter, tidak ada pengelompokkan jenis barang sehingga menyulitkan bagi pedagang karena pembeli susah untuk mencari keberadaan pedagang.

Penelitian ini bertujuan untuk menjelaskan dan mendeskripsikan "Strategi Adaptasi Pedagang Pasa Ateh Bukittinggi Pasca Kebakaran di Pasar Penampungan". Permasalahan yang akan peneliti kaji adalah strategi adaptasi yang dilakukan oleh pedagang. Kehidupan pedagang pasca kebakaran mengalami perubahan serta adanya dampak yang terjadi ketika pedagang pindah dari lingkungan yang dikenalnya ke lingkungan yang kurang dikenalnya. Di Pasar Penampungan banyak masalah yang dihadapi pedagang daya beli rendah serta kios yang berukuran kecil membuat pedagang merasa kesulitan dengan situasi dan kondisi seperti ini sehingga dalam menjalani kelangsungan usahanya dibutuhkan suatu strategi adaptasi dalam mempertahankan usaha tersebut. Berdasarkan batasan masalah di atas, maka yang menjadi pertanyaan pada penelitian ini adalah: Bagaimana strategi adaptasi pedagang Pasa Ateh Bukittinggi pasca kebakaran di Pasar Penampungan. Penelitian ini dianalisis dengan teori Struktural Fungsional oleh Talcott Parsons dianggap relevan dalam mengkaji strategi adaptasi yang dilakukan pedagang Pasa Ateh pasca kebakaran di pasar penampungan. Asumsi dasar dari Teori Fungsionalisme Struktural memandang masyarakat sebagai satu sistem yang terdiri dari bagian-bagian yang saling berhubungan satu sama lain dan bagian yang satu tidak dapat berfungsi tanpa adanya hubungan dengan bagian yang lainya. Kemudian perubahan yang terjadi pada satu bagian akan menyebabkan ketidakseimbangan dan pada gilirannya akan menciptakan perubahan pada bagian lainnya. Asumsi dasar teori ini ialah bahwa semua elemen harus berfungsi atau fungsional sehingga masyarakat bisa menjalankan fungsinya dengan baik. ${ }^{1}$

Penelitian ini akan membahas hasil temuan dengan menggunakan salah satu kerangka skema AGIL yaitu Adaptasi (Adaptation). Menurut Parsons sebuah sistem harus menanggulangi situasi eksternal yang gawat. Sistem harus menyesuaikan diri dengan lingkungan dan menyesuaikan lingkungan itu dengan kebutuhannya. Parson melihat masyarakat sebagai suatu sistem yang mana tiap unsur saling mempengaruhi, saling membutuhkan, dan bersama-sama membangun totalitas yang ada, serta bertujuan untuk mewujudkan keseimbangan. Dalam kasus ini pasca kebakaran kehidupan pedagang mengalami perubahan yang sangat drastis sehingga adanya gangguan pada salah satu elemen yang tidak berfungsi karena fungsi pasar tidak berjalan semestinya, perekonomian pedagang menurun karena pedagang pindah ke tempat yang belum dikenalnya sehingga membuat pedagang demi kelanjutan hidupnya harus bertindak terhadap lingkungan, baik dengan cara menyesuaikan diri pada lingkungan itu atau menguasai dan mengendalikannya.

\footnotetext{
${ }^{1}$ Bernard Raho,SVD , Teori Sosiologi Modern, (Jakarta: Prestasi Pustaka 2007), hlm. 48.
} 


\section{Metode Penelitian}

Penelitian ini dilakukan di Pasar Penampungan Pasa Ateh Bukittinggi, Kota Bukittinggi. Pasa Ateh merupakan satu-satu pasar yang ada di Bukittinggi. Penelitian ini dilakukan dengan pendekatan kualitatif tipe studi kasus. Teknik pengambilan informan yaitu dengan purposive sampling ${ }^{2}$. Penarikan informan penelitian dilakukan dengan sengaja dan peneliti menentukan sendiri kriteria informan penelitian yaitu pedagang Pasa Ateh yang terkena dampak kebakaran. Adapun kriteria informan adalah pedagang yang terkena dampak kebakaran. Selain itu, informan juga diambil dari, ketua bidang pengelolaan pasar berserta staff, pembeli dan pedagang sekitar. dalam hal ini pedagang yang terkena dampak kebakaran yang menjadi informan kunci karena, pedagang yang lebih memahami situasi dan kondisi yang dialami pasca kebakaran di pasar penampungan. Setelah melakukan penelitian informan berjumlah 25 orang yaitu, 1 orang kabid pengelolaan pasar dan 1 orang staff pengelolaan pasar, 16 orang pedagang yang terdampak kebakaran, 4 orang pembeli, dan 3 orang pedagang sekitar.

Teknik pengumpulan data yang dilakukan penelitian ini adalah dengan menggunakan observasi, wawancara, dan studi dokumentasi. Jenis observasi dalam penelitian ini adalah partisipasi pasif, dimana peneliti tidak terlibat langsung didalam objek penelitian. Partisipasi pasif, sewaktu pengumpulan data peneliti hanya menyaksikan, mengamati dan melakukan pengamatan langsung kelapangan tapi tidak ikut terlibat dalam kegiatan tersebut. ${ }^{3}$ Keterlibatan peneliti dengan para pelaku terwujud dalam bentuk keberadaan arena kegiatan yang di wujudkan oleh tindakan-tindakan pelakunya dan peneliti hanya mengamati aktivitas pedagang Pasa Ateh berlangsung tanpa ikut serta dalam aktivitas tersebut.. Wawancara yang dilakukan peneliti adalah wawancara mendalam. Wawancara mendalam dilakukan kepada setiap informan yang dipilih dalam puposive sampling, pertanyaan yang diberikan kepada informan sesuai dengan pedoman wawancara yang telah disediakan. Untuk melengkapi data dokumentasi dilakukan dengan mengambil foto-foto, merekam suara, catatan harian observasi dan catatan harian wawancara terkait dengan strategi adaptasi pedagang di pasar penampungan. Untuk menguji keabsahan data peneliti menggunakan teknik triangulasi data. Jenis triangulasi yang digunakan dalam penelitian ini yaitu triangulasi waktu. Data yang diperoleh di lapangan dianalisis mengacu pada model analisis interaktif yang dikembangkan oleh Miles dan Huberman yang terdiri dari tiga jalur analisis ${ }^{4}$ yaitu reduksi data, penyajian data dan penarikan kesimpulan.

\section{Hasil dan Pembahasan}

\section{Hasil}

Para pedagang yang menjadi korban kebakaran harus beradaptasi dengan lingkungan dan keadaan baru yaitu di Pasar Penampungan sementara yang terletak tidak jauh dari lokasi pasar sebelumnya. Pemindahan pedagang dilokasi sekarang tentunya membuat pedagang harus mampu beradaptasi. Pemindahan para pedagang juga menimbulkan dilema tersendiri seperti berkurangnya pendapatan yang diakibatkan lokasi sebelumnya strategis bagi para pedagang sekarang justru sebaliknya. Beberapa pedagang ada yang mendapatkan kios yang jauh dari keramaian sehingga orang yang berbelanja jumlahnya sedikit dibandingkan sebelum mereka direlokasi. Agar roda perekonomian para pedagang tetap berjalan maka mereka harus mampu beradaptasi di lokasi yang baru. Strategi adaptasi yang dilakukan pedagang Pasa

\footnotetext{
${ }^{2}$ Burhan Bungin.2003.Data Penelitian Kualitatif. Jakarta. PT Rsaja Grafindo Persada. Hlm. 53

${ }^{3} \mathrm{lbid}, \mathrm{hlm} .126$

${ }^{4} \mathrm{Ibid}, \mathrm{hlm} .20$.
} 
Ateh pasca kebakaran di Pasar Penampungan. Adapun strategi yang dilakukan pedagang di pasar penampungan yaitu:

Pertama berdagang di pasar penampungan, berdagang di pasar penampungan untuk penempatan kios dilakukan dengan cara lotting yang bertujuan untuk menghindari konflik antar pedagang. Meskipun pedagang telah menempati kios penampungan daya beli masyarakat masih rendah sehingga pedagang banyak menyewakan kiosnya dan lebih memilih untuk tutup dan mangaleh babelok. Pedagang di pasar penampungan dikenakan biaya retribusi sebesar Rp.2.500 setiap hari sebagai uang keamanan dan kebersihan, dengan keadaan pasar yang sepi pedagang merasa biaya retribusi memberatkan sehingga mengatasi masalah tersebut pedagang memiliki cara yaitu menyisihkan sebagian uangnya untuk berjagajaga jika tidak terjadi jual beli.

Kedua, membangun keakraban sesama pedagang. Di pasar penampungan pedagang memiliki teman lama yang keakrabannya lebih intim sedangkan untuk hubungan keakraban pedagang dengan teman baru masih dalam proses pengenalan karena baru kenal sehingga masih ada rasa segan-menyengan di antara pedagang.

Ketiga mempercantik ruang dan penataan barang yang menarik. Pedagang melakukan permainan aspek ruang dan waktu untuk menarik para konsumen untuk datang atau sekedar untuk melirik. Permainan aspek ruang dan waktu merupakan daya tarik yang dilakukan pedagang untuk saling bersaing di pasar penampungan.

Keempat, mempromosikan barang dagangannya ke konsumen. Dengan pedagang telah menempati kios di pasar penampungan membuat pedagang kehilangan pelanggan karena mereka merasa kesulitan mencari barang yang diinginkannya. Ada usaha yang dilakukan pedagang yaitu dengan memberikan potongan harga atau pemberian diskon kepada konsumen rata-rata yang mendapatkan diskon yaitu mukena, jilbab, bahan kain sulam dan baju anak. Memberikan pelayanan yang baik dan ramah kepada konsumen dan pedagang masih mempertahankan kualitas barang dagangannya.

\section{Pembahasan}

Menurut Parsons, masyarakat adalah sebuah sistem yang terdiri dari bagian-bagian yang saling terhubung satu sama lain dan bagian yang satu tidak dapat berfungsi tanpa adanya hubungan dengan bagian yang lain. Masyarakat Kota Bukittinggi sebagian besar bermata pencarian sebagai pedagang di pasar yang ada di Kota Bukittinggi. Salah satu pasar yang ada adalah Pasa Ateh Bukittinggi. Individu yang berada dan berinteraksi di pasar tersebut telah terbentuk menjadi masyarakat Pasa Ateh. Adanya pedagang, pengelola pasar dan konsumen saling berhubungan satu sama lain. Mereka saling membutuhkan dan saling melengkapi satu sama lain. Jika tidak ada satu bagian dalam masyarakat ini, maka sistem masyarakat ini tidak akan berfungsi dengan baik. Jika tidak ada pedagang maka tidak akan terjadi jual beli. Begitupun dengan bagian masyarakat yang lain.

Adanya perubahan yang terjadi pada satu bagian akan menyebabkan ketidakseimbangan dan pada gilirannnya akan menciptakan perubahan pada bagian lainnya. terjadinya kebakaran di Pasa Ateh menciptakan perubahan pada masyarakat. Pedagang yang awalnya berdagang berdasarkan jenis barang yang mereka jual. Setelah terjadinya kebakaran, mereka berdagang di pasar penampung yang disediakan pemerintah dan berdagang berdasarkan hasil lotting yang dilakukan. Perubahan ini berdampak pada ketidakseimbangan pada aktivitas jual beli di pasar penampungan.

Demi keberlangsungan hidupnya, masyarakat harus menjalankan fungsi dari kerangka skema AGIL yang dibuat oleh Parsons. Salah satu fungsi tersebut adalah fungsi Adaptasi (Adaptation). Sebuah sistem harus menanggulangi situasi eksternal yang gawat. Kebakaran yang terjadi di Pasa Ateh merupakan situasi eksternal yang gawat karena kebakaran terjadi 
diluar kendali masyarakat dan menyebabkan terjadinya perubahan pada sistem yang terjadi di Pasa Ateh. Sistem harus menyesuaikan diri dengan lingkungan dan menyesuaikan lingkungan itu dengan kebutuhannya. Terjadinya kebakaran di Pasa Ateh membuat perekonomian masyarakat lumpuh. Untuk menanggulangi hal tersebut maka pemerintah mendirikan pasar penampungan yang bisa digunakan pedagang untuk kembali berdagang pasca kebakaran. Baik pedagang, konsumen maupun pengelola pasar harus mampu menyesuaiakn diri dengan lingkungan baru mereka di pasar penampungan.

\section{Kesimpulan}

Adapun strategi yang dilakukan pedagang yaitu pertama berdagang di kios yang dibangun oleh pemerintah, menyisihkan sebagian uang untuk biaya retribusi. yang kedua membangun keakraban antar pedagang dan mempromosikan barang dagangan kepada konsumen, hal ini terjadi karena konsumen sulit untuk mencari barang yang diinginkannya sehingga adanya cara yang dilakukan pedagang yaitu mempromisikan keberadaanya serta adanya pemberian diskon atau potongan harga karena daya beli masyarakat rendah. Peneliti mendeskripsikan tentang adaptasi yang dilakukan pedagang Pasa Ateh Bukittinggi pasca kebakaran di pasar penampungan. Diharapakan dengan adanya penelitian ini, dapat menjadi pedoman penelitian tahap lanjut dari sudut pandang yang berbeda. Dalam strategi adaptasi pedagang Pasa Ateh Bukittinggi pasca kebakaran di pasar penampungan masih banyak fokus penelitian yang dapat diungkap salah satunya faktor yang mempengaruhi pedagang masih tetap bertahan di pasar penampungan agar menjadi saran untuk penelitian selanjutnya.

\section{Daftar Pustaka}

Bungin, Burhan. (2003). Data Penelitian Kualitatif. Jakarta. PT Rsaja Grafindo Persada.

Damsar. (1997). Sosiologi Ekonomi. Jakarta: PT Raja

Raho, Bernard SVD.( 2007). Teori Sosiologi Modern, Jakarta. Prestasi Pustaka.

Grafindo Persada.

Wirawan. (2012). Teori-teori Sosial dalam Tiga Paradigma. Jakarta: Kencana Prenada Media Group. 